Smithwick, R. H. (1944). Arch. Surg., 49, 180

Sileglitz, E. J. (1930). Amer. J. med. Sci., 179, 775.

Stocks, P., and Karn, M. N. (1924). Blood Pressure in Early Life. Camb. Univ. Press. Stone, C. T., and Vanzant, F. R. (1927). J. Amer. med. Ass., 89,

Symonds, B. (1923). Ibid., 80, 232.

Terry, A. H. (1923). Ibid., 81, 1283

Tigerstedt, C. (1926). Sk̈and. Arch. Physiol., 48, 138. Cited by Dunbar (1935).

Torgerson, W. R. (1929). P.R. J. publ. Hlth, 5, 438.

Transactions of the International Congress on Life Assurance Medicine, London. 1935.

Tung, C. L. (1927). Arch. intern. Med. 40, 153.

(1928). Chin. J. Physiol., 93, 1. Cited by Krakower (1933-4). (1930). Ibid., 4, 117. Cited by Krakower (1933-4).

Verney, E. B., and Vogt, M. (1938). Quart. J. exp. Physiol.. 28, 253. - (1943). Ibid., 32, 35 .

Volhard, F. (1931). In Mohr and Staehelin's Handbuch der inneren Medizin, 2nd ed., 6, 508

Wallgren, A. (1922). Acta med. scand., 56, 356.

Weiss, M. M., and Prusmack, J. J. (1938). Amer. J. med. Sci., 195, 510 .

Weitz, W. (1923). Z. klin. Med., 96, 151.

- and Sieben, A. (1926). Mïnch. med. Wschr., 73, 2197. Cited by Dunbar (1935).

Wiggers, C. J. (1938). Amer. J. Physiol., 123, 644.

Williams, A. W. (1944a). E. A fr. med. J., 21, 328.

(1944b). Ibid., 21, 368.

Wilson, C., and Byrom, F. B. (1939). . Lancet, 1, 136

- (1941). Quart. J. Med., n.s. 10, 65.

- and Pickering, G. W. (1937-8). Clin. Sci., 3, 343

Wood, J. E., and Cash, J. R. (1939). Ann. intern. Med., 13, 81

Yates, M. R., and Wood, J. E. (1936). Proc. Soc. exp. Biol, N.Y. $34,560$.

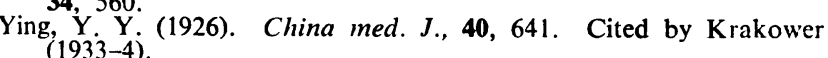

\section{THE ROLE OF INFECTION IN GRANULOPENIA}

BY

KENNETH ROBERTSON, M.D., F.R.C.P.

Physician, Royal Hants County Hospital, Winchester, and Royal South Hants Hospital, Southampton

In 1922 Schultz first reported a condition of severe and progressive oral sepsis associated with granulopenia, which often ended fatally. There can be no doubt that in the earlier cases the importance of sepsis was realized and stressed, but during the twenty years which followed Schultz's paper the aetiological emphasis shifted from infection to the leucotoxic drugs, the administration of which often coincided with the appearance of "malignant neutropenia," as this syndrome was now called.

Reports of cases associated with the taking of compounds containing amidopyrine began to appear on the Continent in 1930, and later in this country. The evidence against these drugs seemed irrefutable, particulariy when it was shown that, in some patients who had recovered, a further small dose immediately produced a profound fall in the number of circulating granulocytes. With further experience other therapeutic agents fell under suspicion, and cases of dangerous neutropenia were reported after the use of organic arsenic, gold salts, sulphonamides, and, more recently, the thiouracils. This list is by no means complete, but is sufficient for the present purpose.

As familiarity with the condition increased, more and more importance was focused upon the leucotoxic agent, while the infection which invariably accompanied the condition came to be regarded as a purely secondary matter, due to invasion of the defenceless organism by bacteria. Thus Wilkinson (1936) uses such phrases as "the primary cause is clearly not bacteriological " and "it is apparently true, however, that the oral, throat, and other ulcerative or necrotic lesions are secondary to the blood condition, and not vice versa."

This view has undoubtedly held the field with little or no question, though all writers on the subject have referred to the fact that malignant neutropenia is from time to time encountered in certain severe infections, particularly staphylococcal septicaemia and osteomyelitis, pneumonia, and liver abscess, when none of the usually accepted leucotoxic drugs have been used. Witts (1936) points out that patients whose white cells have been depressed by one of these drugs may or may not develop the acute illness, depending upon chance exposure to infection. He also refers to animal experiments which seemed to show that such drugs make impossible the normal leucocyte response to infection.

Dameshek and Wolfson (1942) made a preliminary report on the treatment of agranulocytosis by sulphonamides. Nixon, Eckert, and Holmes (1943) described three cases in which agranulocytosis developed while infections were being attacked by sulphadiazine. Instead of withdrawing the drug, it was continued in larger doses, with the result that the blood pictures returned to normal and the patients recovered.

Since these papers, the part played by infection in granulopenic conditions has assumed increasing importance. There can be no doubt that many physicians have accepted Dameshek's advice regarding treatment and no longer worry about the blood picture, concentrating their efforts in overcoming the infection which is threatening to overwhelm the victim.

Boland, Headley, and Hench (1946) reported the cure of a case of total agranulocytosis following the use of gold-a particularly fatal combination-by means of penicillin. In the same paper they refer to fourteen other cases associated with various drugs successfully treated in the same way.

Nevertheless, Israëls (1948), writing of penicillin treatment, says: "Several cases have been reported in the literature, but the results are not very convincing. If there is evidence of sepsis, it is clear that penicillin should be given promptly." Acute agranulocytosis unassociated with sepsis must be exceedingly rare, though Hickie (1948) has described the case of a 70-year-old man whose blood appears to have been almost devoid of cells of the granular series for a period of three years, and in whom it seems that sepsis was infrequently seen, and only as mild superficial episodes.

In March, 1946, I had under my care a woman who developed a complete agranulocytosis while undergoing treatment with gold for rheumatoid arthritis. Two previous similar cases under my care had quickly ended fatally in spite of vigorous treatment, using all the recognized methods of bone-marrow stimulation. In this case penicillin was added to the treatment, and recovery was prompt and complete.

\section{A Series of Cases}

While serving on the Medical Division of a military hospital during 1947 I had the opportunity of treating a number of cases in which severe granulopenia complicated arsenical treatment of syphilis. In addition to N.A.B. all these cases were receiving bismuth, an agent which appears in the list of leucotoxic materials given by Beaumont and Dodds (1947), though I have been unable to discover the report of any case in which granulopenia followed the use of bismuth without arsenic.

In the earlier cases British anti-Lewisite (BAL), "pentide," blood transfusion, ascorbic acid, liver extract, and other bone-marrow stimulants were used in addition to penicillin. In six subsequent cases penicillin alone was employed, with very satisfactory results. McManus (1946) records a similar experience. A case of " arsenical agranulocytosis" treated with BAL and pentide failed to improve until penicillin was added to the treatment. In a second case cure was rapidly achieved by the use of penicillin alone. 
In every instance sepsis, particularly in the mouth, was striking and severe, and haematological improvement went hand in hand with resolution of the infection. This was so striking that I wondered if the infection was of greater importance in the causation of the condition than the arsenic. I wondered, too, if it could be shown that cure could be assured, provided the infection was controlled, even when further arsenic was administered. Further cases of arsenical granulopenia provided the material necessary to put this view to the test.

Several doses of N.A.B. were given to a man (Case 1) immediately after his recovery from the acute illness, for which he had been treated with penicillin alone. These produced no untoward effects either clinically or in the blood picture, and he went on to complete his full course of antisyphilitic treatment. In Case 2 the same procedure was followed, with the same result.

It now remained to observe the effect of arsenic administered before the acute illness had been controlled. In Case 3, 0.6 g. of N.A.B. was given 24 hours after starting penicillin. This appeared to make no difference to the patient's response to treatment. In Case 4 a full dose of N.A.B. was given before starting penicillin treatment. In this case recovery was somewhat delayed, but it was discovered that the infection involved a penicillinresistant strain of staphylococcus, and the local sepsis did not respond until very large doses of the antibiotic had been given. The haematological improvement followed immediately upon control of the local infection. Reports of the four cases are given below.

\section{Case 1}

A private soldier aged 25 was admitted seven weeks after starting routine treatment for a dark-ground-positive chancre. Treatment had been interrupted by mild febrile reactions to arsenic injections, and on admission he had received $3.15 \mathrm{~g}$. of N.A.B. and $1.4 \mathrm{~g}$. of bismuth in addition to $4 \mathrm{mega}$ units of penicillin.

He presented with gross oral sepsis, the gums, which were swollen and congested, being particularly affected. His temperature was $104^{\circ} \mathrm{F}$. $\left(40^{\circ} \mathrm{C}\right.$.) and his pulse rate 110 . There was considerable adenopathy involving all the superficial glands, his spleen was palpable, and he was covered with a wellmarked pigmented secondary syphilide. His white cells numbered 5,000 per c.mm.. only $5 \%$ of which were of the granular series (total polymorphs 250). The Kahn test was positive, two units, and the Paul-Bunnell test negative. He was treated with 50,000 units of penicillin three-hourly. At the end of 48 hours, with his temperature falling and his mouth improving, his white cells numbered $6,000,24 \%$ of which were granulocytes (total 1.440). On the fifth day his temperature was normal, and his mouth almost normal, while his white count had risen to 7,600 , $43 \%$ polymorphs (total 3,268). Two days later, the penicillin being continued, 0.3 g. of N.A.B. was injected intravenously. There was a slight febrile reaction, but his white cell count remained satisfactory; indeed, when comparing counts made immediately before the injection with those made at 12 and 18 hours after the injection there was a definite increase in the number of circulating polymorphs.

Two days later a further injection of $0.45 \mathrm{~g}$. of N.A.B. was given. To this injection there was no reaction, but 36 hours later he showed a leucocytosis of 20,000 with $65 \%$ polymorphs (total 13,000). During this stage of treatment penicillin cover had been maintained. This was now discontinued, and he subsequently completed his course of antisyphilitic treatment with N.A.B. and bismuth without further incident, his blood count remaining normal throughout.

\section{Case 2}

A soldier aged 24 should have received his final dose of N.A.B. and bismuth on July 5. This was withheld because of swollen gums, and he was referred to the dental department. $\mathrm{He}$ was admitted three days later with a temperature of $104^{\circ} \mathrm{F}$. $\left(40^{\circ} \mathrm{C}.\right)$, pulse 130 , and showing gross swelling of his lower jaw, gingivitis, and many boils on the arms and trunk. He had received $7.5 \mathrm{~g}$. of N.A.B. and $2.6 \mathrm{~g}$. of bismuth. His blood showed 3,650 white cells per c.mm., with $10 \%$ polymorphs (total 365). The Kahn test was negative. Penicillin was started, 50,000 units being given every three hours. His response was immediate, and in 24 hours his temperature had fallen to $100^{\circ} \mathrm{F}$. $\left(37.8^{\circ}\right.$ C.) and there was considerable local improvement, while his polymorph count had risen to 896. Three days later the condition of his mandible and gums seemed normal. while all his boils had healed and his white cell count showed that $56 \%$ of 3,600 cells were polymorphs (total 2,016 ). Penicillin was discontinued, and two days later, with a normal white cell count, he was given 0.45 g. of N.A.B. intravenously. Thirtysix hours after the injection he showed a leucocytosis of 14,000 , with $64 \%$ polymorphs (total 8,960 ). Two weeks later his white cell count was normal.

\section{Case 3}

A 43-year-old officer received his fifth injection of arsenic on Oct. 16. The total amount of arsenic received was $2.55 \mathrm{~g}$. On the 18th his mouth and gums became painful. He was admitted on Oct. 25 with high fever, great swelling of the gums, and buccal ulceration. His white cell count was 6,200 per c.mm., with $18 \%$ polymorphs (total 1,116 ). Treatment was withheld, and the next day his count had fallen to 5,100 , with $16 \%$ polymorphs (total 816). Penicillin was now started-50,000 units three-hourly-and by the 27 th, with clear-cut clinical improvement, his white cells had increased to $6,000,32 \%$ of which were polymorphs, $9 \%$ being eosinophils (total granulocytes 2,460). N.A.B. 0.6 g. was given intravenously on this day. An urticarial rash resulted, lasting 24 hours. Next day, with his temperature normal and showing marked local improvement, his white cell count had improved to $7,100(52 \%$ polymorphs, $7 \%$ eosinophils; total granulocytes 4,189 ). From this point his illness rapidly resolved, and he was discharged to continue his course of antisyphilitic treatment, without further episode.

\section{Case 4}

A private soldier aged 20 was admitted on Dec. $3 . \mathrm{He}$ had received $1.95 \mathrm{~g}$. of N.A.B. and $0.8 \mathrm{~g}$. of bismuth. The earlier stages of his arsenical treatment had been decelerated on account of some skin reactions. Two days before admission he had felt ill, with pain in his left cheek. The next day the cheek was swollen and a sty had developed on the right lower lid. He reported sick and was sent to hospital 24 hours later. He then had a temperature of $104^{\circ} \mathrm{F}$. $\left(40^{\circ} \mathrm{C}\right.$. $)$ and showed all the signs of considerable toxaemia. On the buccal surface of the left cheek there was a deep painful ulcer. The left lower lid had a staphylococcal infection, and furuncle was present on his chin. A blood count showed 4,200 white cells per c.mm., $2 \%$ of which were polymorphs (total 84 ). Before the beginning of treatment he was given $0.6 \mathrm{~g}$. of N.A.B. Two hours later penicillin was started in 100,000-unit doses every three hours. The next day his white count had fallen to 2,400 and no polymorphs could be seen in a smear. Subsequent counts were as follows:

\begin{tabular}{|c|c|c|c|c|c|c|}
\hline \multicolumn{3}{|c|}{ Date } & Leucocytes & Polymorphs & Eosinophils & Total Granulocytes \\
\hline $\begin{array}{l}\text { Dec. } \\
\text { ", } \\
, " \\
, " \\
, " \\
, "\end{array}$ & $\begin{array}{r}5 \\
6 \\
7 \\
8 \\
9 \\
10 \\
11 \\
12 \\
15 \\
20\end{array}$ & $\begin{array}{l}\cdots \\
\cdots \\
\cdots \\
\cdots \\
\cdots \\
\cdots \\
\cdots\end{array}$ & $\begin{array}{l}2,600 \\
4,300 \\
4,000 \\
5,500 \\
4,400 \\
8,800 \\
7,000 \\
7,150 \\
9,350 \\
8,000\end{array}$ & $\begin{array}{r}4 \% \\
6 \% \\
10 \% \\
15 \% \\
17 \% \\
14 \% \\
36 \% \\
35 \% \\
46 \% \\
60 \%\end{array}$ & $\begin{array}{r}13 \% \\
8 \% \\
3 \% \\
7 \% \\
4 \% \\
9 \% \\
4 \% \\
8 \% \\
6 \% \\
2 \%\end{array}$ & $\begin{array}{r}442 \\
602 \\
520 \\
1,210 \\
924 \\
2,024 \\
2,800 \\
3,074 \\
4,862 \\
4,960\end{array}$ \\
\hline
\end{tabular}

On Dec. 6 the staphylococcus obtained from his lesions was reported to be penicillin-resistant. The dose of penicillin was immediately doubled. At this time, though his temperature had subsided and his general condition was excellent, the buccal ulcer was showing no signs of healing. During the next few days this situation was reversed and the ulcer healed steadily.

It will be seen that restitution of the blood picture was delayed, and it seems reasonable to assume that this was 
related to the fact that the infecting organism proved relatively resistant to penicillin and that it was not subjugated until the dosage was considerably increased. This patient received in all 15 mega units of penicillin.

\section{Discussion}

In this small investigation it appeared that infection was playing the major part in the aetiology of the condition, and that its control allowed recovery of the bone marrow, a recovery which further arsenic was unable to prevent.

In other conditions associated with granulopenia I have noticed serious deterioration as a result of superadded infection. A man convalescent from glandular fever sustained a streptococcal infection of his throat. His polymorphs promptly fell from 1,800 to 90 per c.mm., to rise again immediately the infection had been subdued by penicillin. A woman suffering from chronic lymphatic leukaemia developed gross infection in her mouth and throat. This resulted in a grave illness, with high fever, widespread purpura, and a rapid fall in the haemoglobin level, which reached $25 \%$. Treatment with parenteral and intraoral penicillin rapidly overcame the infection, the fever fell to normal, the mouth lesions healed, the purpura vanished, and the haemoglobin began to rise, eventually reaching over $100 \%$. She has remained well during six months' subsequent observation, though her blood picture is still, of course, that of chronic lymphatic leukaemia. In other cases of leukaemia acute and threatening episodes have been initiated by sepsis, the control of which has resulted in temporary improvement in the patient's condition.

There seems to be little doubt that a functionally damaged bone marrow is particularly vulnerable to the toxins resulting from sepsis. It is well known, for example, that infection can interfere with the full therapeutic effect of liver extract in the treatment of Addisonian anaemia.

The factors giving rise to neutropenia are doubtless multiple. In addition to the part played by leucotoxic drugs-and no one will challenge this factor-it seems that idiosyncrasy, sensitization, age, sex, and endocrine factors must all be taken into account. But it may well be that infection, which is, I believe, the only factor common to almost every case, is the most important of all. A recognition of this possibility is clearly of considerable therapeutic and preventive importance. It would seem wise to exclude sepsis in cases of rheumatoid arthritis and thyrotoxicosis before embarking upon treatment with gold or the thiouracils. At the same time patients undergoing treatment by any of the recognized leucotoxic drugs should be warned to avoid infection and to report the smallest infective process immediately. Printed instructions might be valuable from this point of view. It is doubtful if the white cell count is of any value in giving warning of white cell depression, and may even lead to a false sense of security.

It has always been said that the appearance of a blood dyscrasia while undergoing treatment by any of these drugs precludes for ever the use in such a patient of the particular material thought to have been causative. The observations recorded here suggest that this dictum may not need to be adhered to when there are indications for further administration of the offending preparation. McGibbon and Glyn-Hughes (1943) came to the same conclusion after describing a case of agranulocytosis following arsenic.

In 1942 a fulminating case of agranulocytosis under my care, following the use of sulphapyridine, was given after recovery $3 \mathrm{~g}$. of the drug by intravenous injection. Frequent white cell counts made during the subsequent 48 hours revealed no fall in the number of granulocytes.

\section{Conclusions}

It is suggested that in conditions of serious neutropenia infection plays a predominant part ; that in its prevention, while undergoing treatment with possibly leucotoxic drugs, avoidance of infection, both endogenous and exogenous, is of more importance than repeated blood examinations ; and that in the treatment of the established condition attention should be centred upon the immediate arrest of the infective process by the free use of the most suitable specific drug, which at present is likely to be penicillin in most cases. It should be given in large doses, in the region of 1 mega unit daily. In these circumstances pentide, blood transfusion, etc., may with advantage be withheld during the first 72 hours. If there has been no response at this stage pentide should be started and continued until response is well established. Fresh blood, folic acid, pyridoxin, ascorbic acid, liver extract, and thyroid may all be useful in individual cases. Where there has been satisfactory response to penicillin alone it may be possible to resume the supposedly leucotoxic drug, if necessary.

My thanks are due to the Director-General, Army Medical Services, for permission to publish this paper, and to Brigadier F. J. O'Meara, Consulting Physician, B.A.O.R., Colonel C. A. Gavan Duffy, Officer Commanding Medical Division, 94th (Hamburg) British Military Hospital, Colonel F. E. Buckland, Director of Pathological Services, B.A.O.R., and Captain W. T. Hendry, for their interest and help in this investigation.

\section{REFERENCES}

Beaumont, G. E., and Dodds, E. C. (1947). Recent Advances in Medicine, 12 th ed., p. 333. London

Boland, E. W., Headley, N. E., and Hench, P. S. (1946). Proc. Mayo Clin., 21, 197.

Dameshek, W., and Wolfson, L. F. (1942). Amer. J. med. Sci., 203, 819,823 .

Hickie, G. (1948). Quart. J. Med., n.s. 17, 165.

Israëls, M. C. G. (1948). In Daley and Miller's Progress in Clinical Medicine, p. 199. London.

McGibbon, C., and Glyn-Hughes, F. (1943). Lancet, 1, 173.

McGibbon, C., and Glyn-Hughes, F. (1946). New. Engl. J. Med., 234, 17.

Nixon, N., Eckert, J. F., and Holmes, K. B. (1943). Amer. J. med. Sci., 206, 713 .

Schultz, W. (1922). Dtsch. med. Wschr., 48, 1495

Wilkinson, J. F. (1936). In Rolleston's British Encyclopaedia of Medical Practice, 1, 262. London.

Witts, L. J. (1936). British Medical Journal, 1, 1061

\section{INSTRUCTION OF THE MEDICAL STUDENT IN PAEDIATRICS AN INSIGHT INTO FAMILY PRACTICE}

BY

\section{W. S. CRAIG, M.D., F.R.C.P.Ed., M.R.C.P. F. CHARLOTTE NAISH, M.D. AND}

\section{F. G. BUCHANAN, M.B., Ch.B.Ed., D.C.H.}

Instruction of the medical student is concerned primarily with the training of the future family doctor. Undergraduate training suffers from having to be provided under conditions dominated by hospital considerations of disease. As a result the recently qualified doctor entering general practice has to adjust his outlook. He is not long in practice before he realizes that many of the problems which appeared simple of solution when seen in hospital are complex when considered in relation to the needs of the home. Short of restoring the old-time apprenticeship system it is difficult to see how this handicap can be completely offset.

The handicap applies particularly to undergraduate study of health and disease in infancy and childhood. Ward instruction is deficient because of the absence of the mother and of any visual reminder of home conditions. The 